\title{
Jämställdhets- integrering vid svenska universitet och högskolor. Det politiska uppdraget återspeglat i lärosätenas planer
}

\section{Af Birgitta Jordansson och Helen Peterson}

\begin{abstract}
Gender Mainstreaming in Swedish Higher Education: the political directive reflected in institutional plans. The Swedish government's latest reform of gender inequality in higher education set out to strengthen gender mainstreaming. Following this reform, the Swedish higher education institutions established gender mainstreaming plans for 2017-2019. In this article, we analyse and discuss the content of these plans, focusing on how they describe the organisation of gender mainstreaming, the understanding of gender inequality as a problem, and the planned activities to achieve gender mainstreaming. Drawing on interpretative frame theory, we identify challenges with the aims and scopes of these plans and the definitions they employ, e.g. in attempts to merge gender mainstreaming with the already on-going equal opportunity work based on the Swedish Discrimination Act. We conclude that many institutions have adopted an approach to gender mainstreaming that has the potential for transformation through long-term and sustainable cultural and structural change. To what extent the plans will be fully implemented, however, remains to be investigated, and depends on the organisation of work, commitment of leaders, and legitimacy of practitioners.
\end{abstract}

\section{KEYWORDS}

gender equality policy; gender mainstreaming; higher education; interpretative frame theory; Sweden; university

Birgitta Jordansson, fil dr i historia och docent i arbetsvetenskap vid Institutionen för sociologi och arbetsvetenskap, Göteborgs universitet.

Helen Peterson är docent i sociologi och lektor i arbetsvetenskap vid Institutionen för sociologi och arbetsvetenskap vid Göteborgs universitet. 


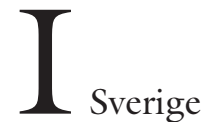

har det under lång tid funnits en stark tilltro till politiska lösningar på problemet med de ojämnställda villkoren inom akademin. Det har i hög grad handlat om återkommande politiska insatser för att öka andelen kvinnliga professorer. En långsam ökning har också skett. Den första, mer påtagliga ökningen - från sju till elva procent följde av den politiska satsningen på 30 nya professurer med inriktning mot underrepresenterat kön under senare delen av 90talet, de så kallade Thamprofessurerna (Jordansson 1999). De återkommande treåriga rekryteringsmål som regeringen sedan 1997 satt upp för lärosätena har bidragit till att andelen kvinnliga professorer nått upp till 28 procent (UKÄ 2018). Även andelen kvinnliga akademiska ledare har successivt ökat (Peterson 2017).

Trots ett politiskt engagemang konstateras återkommande att ojämställdheten inom akademin kvarstår i form av obalans på professorsnivå, ojämställda karriärvägar, resursfördelning och arbetsvillkor (UHR 2014; Statskontoret 2014). De politiska satsningarna fortsätter därför (prop. 2016/ 17:50). Det senaste regeringsuppdraget till svenska lärosäten är JiHU - Jämställdhetsintegrering av högskolor och universitet, som löper mellan 2017-2019. Helene Hellmark Knutsson, dåvarande minister för högre utbildning och forskning, lanserade på följande vis uppdraget 2016:

Sverige har en feministisk regering. Det betyder att jämställdhet står högt på agendan. Och det betyder också att vi har en plikt att verka för reell förändring. $\mathrm{Nu}$ börjar arbetet för att kompetens ska vara styrande för högskolan och för att alla talanger ska tas tillvara. (Hellmark Knutsson 2016)

Uppdraget specificerades i regeringens regleringsbrev till lärosätena 2016. I detta ålades universitet och högskolor att ta fram en plan för arbetet med jämställdhetsintegrering i syfte att verksamheten ska bidra till att nå de jämställdhetspolitiska målen, exempelvis i fråga om lika möjligheter till karriärvägar, könsbundna studieval och genomströmning. Planen skulle vara upprättad och fastställd senast den 15 maj 2017 och innehålla utvecklingsbehov, mål och aktiviteter som lärosätet avsåg att vidta och genomföra under 2017-2019 för att integrera jämställdhet i den ordinarie verksamheten, bland annat i lärosätets styrprocesser. Nationella sekretariatet för genusforskning vid Göteborgs universitet fick i uppdrag att fungera som ett stöd åt lärosätena i arbetet genom att anordna nätverksträffar och samordna kompetenshöjande insatser (Regleringsbrev för budgetåret 2016 avseende universitet och högskolor).

Utöver direktiven i regleringsbrevet fick lärosätena en hög grad av frihet att själva tolka uppdraget och ansvaret för utformningen av arbetet överläts på de enskilda lärosätena. I föreliggande text undersöker vi hur det nya uppdraget återspeglas i dessa planer. Syftet med artikeln är att analysera innehållet i planerna för att skapa en djupare förståelse för hur svenska lärosäten har tolkat uppdraget om jämställdhetsintegrering. I vilken utsträckning återspeglar planerna möjligheter till reell förändring (som forskningsministern efterfrågade $\mathrm{i}$ citatet ovan)?

\section{TIDIGARE FORSKNING}

Uppdraget om jämställdhetsintegrering ska förstås mot bakgrund av att jämställdhet har stått på agendan för svenska universitet och högskolor sedan mer än 25 år. I Högskolelagen (1992:1434) och Högskoleförordningen (1993:100) definierades tidigt övergripande mål om jämställdhet. Som komplement till dessa beslutade Sveriges riksdag om ramarna för ett treårigt utbildningsuppdrag (prop. 1992/93:169) 
och för forskningspolitiken (prop. 1992/ 93:170). De politiska uppdragen och kraven på jämställdhetsåtgärder har sedan dess regelbundet återkommit. Med propositionen Delad makt - Delat ansvar (prop. 1993/94:147) slogs det fast att jämställdhetsintegrering skulle vägleda jämställdhetsarbetet $\mathrm{i}$ all offentlig verksamhet, även universitet och högskolor. Integrering av jämställdhet innebär att jämställdhetsperspektivet genomsyrar allt beslutsfattande, all planering och allt utförande och kräver en: “(om)organisering, förbättring, utveckling och utvärdering av beslutsprocesser" (SCB 2004, 6). Det betyder att jämställdhetsarbetet ska bedrivas inom ramen för den ordinarie verksamheten. Något år senare accentuerades detta ytterligare då det hette att "ett jämställt forskarsamhälle" varken krävde "extra resurser eller ny lagstiftning utan medvetenhet, flexibilitet, uppfinningsrikedom, vilja och handlingskraft" (prop. 1994/95:164, 37). Kraven på lärosätena var explicita men det fanns även en uppenbar misstro gentemot deras förmåga att handla. I sin undersökning av svensk forskningspolitik under senare delen av 90-talet intervjuade Mats Benner dåvarande utbildningsministern Carl Tham, som motiverade politiken på följande sätt:

Universiteten och dess ledande företrädare ansågs helt enkelt oförmögna till en genomgripande förändring av arbetsformerna och villkoren för kvinnor och män (Benner 2001, 137)

Det är i ljuset av detta misstroende som de konkreta politiska satsningarna ska ses; däribland särskilda paket för att stödja genusforskarmiljöer med genusprofessurer (professurer med inriktning mot genusforskning), forskarassistenttjänster och doktorandtjänster (prop. 1994/95:164; prop. 1996/97:5).

Signifikant för de politiska åtgärderna har varit sammankopplingen mellan satsningar på jämställdhet och stöd till jämställdhets- /kvinno-/genusforskningen (prop. 2016/ 17:50; SOU 1995:110; SOU 2011:1). Redan vid mitten av 90-talet hette det att “jämställdhet förutsätter grundläggande kunskaper om rådande könsmönster" (prop. 1994/95:164, 11). De politiska kraven på lärosätenas ledningar att ta ansvar och agera för ökad jämställdhet handlade därmed om att öka andelen kvinnor men också om att stärka genusforskningen som skulle bidra med kunskap för det praktiska jämställdhetsarbetet.

Trots de politiska intentionerna att koppla samman jämställdhet med genusforskningen har forskningsfältet framhållit det stora avståndet mellan regeringens officiella jämställdhetspolitik, med fokus på fler kvinnliga professorer, och den komplexa, forskningsbaserade förståelsen av hur normer, processer och strukturer producerar och reproducerar könsordningen (Alnebratt 2009; Liinason 2010; Powell 2016; Winther Forsbäck 2017).

Kopplingen mellan jämställdhet och kvinno-/genusforskning har dock förstärkts av att engagerade forskare varit drivande $i$ jämställdhetsarbetet. Dessa 'eldsjälars' initiativ har ofta möjliggjorts via statliga medel som sökts i nationell konkurrens (Heikkilä och Häyrén Weinestål 2009). Den första utlysningen av sådana medel kom när Utbildningsdepartementet tillsatte den så kallade JÄST-gruppen (Jämställdhet för kunskap, insikt och kvalitet) för att administrera lokala projekt ute på lärosätena under perioden 1993/94-1996/97. Under dessa år finansierades 122 projekt till en sammanlagd kostnad av 28 miljoner. Mellan åren 2009-2010 genomfördes ytterligare 37 lokala projekt, understödda av Delegationen för jämställdhet i högskolan (Dir. 2009:7), med en budget på 47 miljoner kronor (UHR 2014).

De politiska satsningarna har lett till nya arbetsformer, metoder och rutiner samt ökad acceptans för jämställdhetsarbete. Utvärderingar och forskning visar dock fortsatt på svårigheterna med att implementera 
de politiska uppdragen (Lewander och Jordansson 2000; Peterson och Jordansson 2017; SOU 2011:1; Statskontoret 2014). Arbetet försvåras av olika typer av hinder och motstånd (Angervall 2005; Dahlerup 2010; Muhonen, Liljeroth och Scholten 2012), bristande långsiktighet och planmässighet (Lewander och Jordansson 2000) samt oklara mandat att agera (Lindholm 2014). Förankring på ledningsnivå och organisatoriskt ansvar tycks på många håll ha saknats (Jordansson 2017). När jämställdhetsarbetet delegeras till kommittéer och enskilda engagerade individer riskerar det att sidoorganiseras och aldrig riktigt integreras i den akademiska kärnverksamheten (Powell 2016; Rönnblom m.fl. 2014). Det finns även en risk med att jämställdhetsfrågor avpolitiseras och blir till administration $\mathrm{i}$ form av statistik, indikatorer och rankningar (Rönnblom m.fl. 2014). Planerna för jämställdhet och lika villkor blir då enbart 'pappersprodukter' (Lindholm 2014, 59).

Trögheten när det gäller att implementera de politiska uppdragen kan också förstås om vi betraktar lärosäten som organisationer med två delvis sidoordnade styrsystem som det uppstår spänningar emellan. Det ena systemet bygger på att offentligt driven verksamhet ska följa lagar och regler utformade av riksdag och regering, vilket under senare år lett till en omfattande linjestyrning med en tydlig chefs- och beslutshierarki från rektor ned till prefekter (Bremer 2015). Det andra systemet vilar på lärosätenas grundlagsskyddade självständighet och forskningens och forskarens frihet och tar sig uttryck i institutionell autonomi och kollegial 'inre' styrning (Merton 1973; prop. 2009/10:149; SOU 2008:104). Politiska ingrepp i den vetenskapliga verksamheten uppfattas enligt den kollegiala logiken som otillbörlig påverkan på akademiska värden och ett brott mot den omutlighet som är en av grundpelarna för vetenskaplig aktivitet. Medan centralt fastlagda mål och arbetsgivaransvar hanteras i linjeorganisationen beslutas därför många frågor som rör forskningens och undervisningens innehåll av kollegiet/medarbetarna.

Jämställdhet är del av ett lagstadgat arbetsgivaransvar men det är svårt att bortse ifrån att det också handlar om den vetenskapliga vardagen och de kollegiala beslutsprocesserna, vilka återkommande visats gynna vissa män (Sandström m.fl. 2010; Öhrn och Lundahl 2013). Spänningen förstärks genom en grundläggande motsättning mellan jämställdhetsarbete med utgångspunkt $\mathrm{i}$ att det finns normer som gör att kvinnor och män bedöms på olika sätt, och den akademiska meritokratin som lyfter fram och betonar att det är objektiva och mätbara meriter som ligger till grund för tjänstetillsättning, befordran och avancemang (Powell 2016).

Slutligen finns det ytterligare en omständighet att beakta, av relevans för lärosätenas arbete med jämställdhetsintegrering. Sedan 2009 inordnas jämställdhet i det aktiva och planmässiga arbetet för att främja lika rättigheter baserat på diskrimineringsgrunderna kön, könsidentitet, etnisk tillhörighet, religion eller annan trosuppfattning, funktionsnedsättning, sexuell läggning och ålder (SFS 2008:567, 3 kap.). Svenska lärosäten har i enlighet med detta och utifrån direktiven från Diskrimineringsombudsmannen (DO) upprättat likavillkors-/likabehandlings-/mångfaldsplaner (olika rubriker används vid olika lärosäten), omfattande diskrimineringsgrunderna men även frågor om breddad rekrytering (Lindholm 2014).

Det åläggs alltså nu lärosätena att hantera två närbesläktade men ändå olika uppdrag - att arbeta aktivt utifrån Diskrimineringslagen samt att jämställdhetsintegrera verksamheterna. Det förstnämnda handlar om ett lagstyrt arbete med fokus på individen och på förbättrade villkor. Jämställdhetsintegrering är däremot målstyrt med sikte på förändring av lärosätenas dagliga verksamhet (prop. 2016/17:50). När de två uppdragen ska löpa parallellt kan det leda till otydlighet, motsägelser och paradox- 
er. Hur detta hanteras blir därför en springande punkt för vår analys av planerna.

\section{METOD OCH TOLKNINGSRAM}

I slutet av våren 2017 skickade 31 lärosäten in sina planer för jämställdhetsintegrering till Nationella sekretariatet för genusforskning. Det är dessa 31 planer vi granskar i artikeln. Generellt kan styrdokument och handlingsplaner av den här typen förstås både som strategiska texter och exempel på organisationsintern kommunikation. De avspeglar lärosätets förståelse av jämställdhetsintegrering men även av jämställdhet som en del av den värdegrund som lärosätet bygger sin självbild på. Genom planerna kommuniceras detta både till omgivningen och till organisationens egna medlemmar (Nielsen 2014).

Analysen av planerna inspirerades av feministisk policyanalys som syftar till att synliggöra tystnader, icke-beslut och begränsningar och förstår policy som inbäddad i kultur, makt och normer (Marshall 1999). Den här typen av analys undersöker hur policy influeras av dominerande tolkningsramar och meningsskapande. Även om policyanalys inte direkt fokuserar på implementering och praktiker så kan den bidra till att lyfta fram centrala och avgörande möjligheter och begränsningar för det praktiska arbetet. Policydokument beskriver och begreppsliggör aktiviteter; de skapar en kedja av operationaliserade aktiviteter (Saarinen 2008).

Rent praktiskt inleddes analysen av planerna med att de lästes igenom upprepade gånger med fokus på struktur och innehåll. Omfattningen på planerna skiljer sig åt och medan några är ungefär 30 sidor består andra enbart av så kallade aktivitetsplaner (matriser med planerade aktiviteter). Den initiala läsningen resulterade emellertid i att fyra övergripande mönster identifierades: jämställdhetsarbetets organisering, tidigare arbete vid lärosätet, problemformuleringar och kunskapsbas samt planerade aktiviteter och åtgärder. Efter att dessa mönster identifierats tog en mer fokuserad, kvalitativ innehållsanalys vid (Finfgeld-Connett 2013). Det innebar en systematisk kategorisering av innehållet i planerna samt en holistisk tolkning av innehållet i dess kontext.

I analysen användes en teoretisk utgångspunkt i feministisk teori om tolkningsramar. Teorin utgår från att jämställdhet oftast förstås, och ges mening, inom fyra tolkningsramar. Dessa ramar bestämmer vilka åtgärder och aktiviteter som anammas, vilket i sin tur påverkar i vilken utsträckning jämställdhetsarbetet leder till förändring (Ely och Meyerson 2000; Meyerson och Kolb 2000).

Inom den första tolkningsramen definieras jämställdhet handla om att kvinnor behöver stöd, hjälp och uppmuntran. Insatser som föreslås handlar därför om att ge kvinnor möjlighet att utveckla egenskaper och erhålla kunskaper och kvalifikationer som gör att de kan konkurrera med männen. Den andra tolkningsramen förespråkar medvetandehöjande åtgärder för att uppvärdera kvinnors bidrag och det kvinnliga. I den tredje tolkningsramen ligger fokus på att genom interventioner och åtgärdsprogram undanröja strukturella hinder och skapa lika möjligheter. Åtgärderna som föreslås inom de här tre tolkningsramarna har alla begränsningar i det att de inte utmanar normer och maktförhållanden. De kan leda till förbättringar för enskilda kvinnor men tenderar även att medföra anpassningar till de givna förutsättningarna. Möjligheter till förändring sker istället inom den fjärde ramen där angreppssättet betonar komplexiteten i organisatoriska maktförhållanden och att jämställdhet i organisationer kräver genomgripande omstrukturering av arbetet och förändring av rådande normer, kultur och stereotyper. Men det betyder samtidigt att jämställdhetsarbete utmanar dagliga rutiner, positioner och maktrelationer vilket innebär att förändringsarbetet går långsamt och möter motstånd (Ely och Meyerson 2000; Meyerson och Kolb 2000; Nielsen 2017). 
Nedan följer tre resultatavsnitt där vi i det första synliggör några typiska exempel på hur uppdraget om jämställdhetsintegrering återspeglas i planerna som ett arbete som framförallt syftar till förbättring men också anpassning, snarare än förändring. Exempel på förändringspotential finns emellertid också i planerna och dessa lyfter vi fram i avsnittet därefter. I det tredje avsnittet fördjupas analysen med utgångspunkt i de fyra tolkningsramarna. Fokus i alla tre avsnitten ligger på att identifiera begränsningar, men också på möjligheter, med att bedriva jämställdhetsarbete såsom det beskrivs i planerna. Av forskningsetiska hänsyn har vi valt att inte kritisera enskilda planer. Däremot hänvisar vi till vissa intressanta exempel.

\section{JÄMSTÄLLDHETSINTEGRERING SOM FÖRBÄTTRING OCH ANPASSNING}

Jämställdhetsintegrering beskrivs i många planer som en ytterst komplex process som innebär att förändra organisationskulturen och strukturen. Det här leder till ett upplägg där arbetet konkretiseras under processens gång. Det handlar därför i många fall om inriktningsplaner. Planerna skiljer sig på detta sätt tydligt från existerande likabehandlings-/likavillkorsplaner vid lärosätena där jämställdhetsarbetet under senare år beskrivits tillsammans med bland annat frågor om integration, mångfald, HBTQ och religionsutövning. Ett exempel som synliggör att det handlar om inriktningsplaner är Karlstads universitet som skriver att: " $/ \mathrm{p} / \mathrm{la}$ nen sträcker sig fram till delmål och aktiviteter som identifierar vad som ska göras respektive uppnås. Nästa steg blir att tydliggöra bur, av vem/vilka och mer preciserat när" (s. 3). Åtgärdsförslagen som presenteras i planerna är därför ofta mycket allmänt formulerade. Det handlar bland annat om att genomlysa och analysera processer för att kunna förändra dem. Men det här leder samtidigt till att det sällan framgår hur lärosätena konkret tänker sig arbetet.
Läsningen av planerna visar att organiseringen av jämställdhetsintegreringen på de olika lärosätena i hög grad präglas av det arbete som bedrivits tidigare och då ofta inom ramen för likavillkorsarbetet. Rent praktiskt inordnas nämligen ofta arbetet med jämställdhetsintegreringen inom ramen för pågående arbete med lika villkor (t.ex. Högskolan i Dalarna och Uppsala universitet). Flera planer beskriver hur grupper som tidigare arbetat med likavillkorsfrågor är direkt delaktiga och får rollen som lokalt ansvariga eller genom att de, som medlemmar i en referensgrupp, getts möjligheter att bidra i utvecklingen av planen.

Vid ett av de större universiteten är likavillkorsombuden ute i verksamheterna också utsedda till lokala samordnare för jämställdhetsintegreringen. Arbetet blir här beroende av hur det lokala samordningsuppdraget uppfattas av ombuden och hur avgränsningar till det lagstyrda arbetet med diskrimineringsgrunderna hanteras. Centralt erbjuds stöd och verktyg för att arbeta på lokal nivå men förankringen i kunskapsfältet - genus och jämställhet - är inte framskriven. Risken finns att det etablerade lagstyrda likabehandlingsarbetet fortsatt prioriteras, speciellt om inte de lokala samordnarna făr mer tid i sin tjänst för att också implementera principerna för jämställdhetsintegrering i verksamheten. Den eventuella förändringspotentialen riskerar dessutom att bli personberoende och relaterad till dessa likabehandlingsombuds egna kompetenser - och intressen - inom området.

Rollen som samordnare för jämställdhetsintegreringen på central nivå har ofta gått till personer placerade vid lärosätenas stabsfunktioner eller HR-avdelningar. Möjligheterna att utifrån dessa positioner även utmana eller förändra organisationsstrukturen riskerar dock att bli begränsade. När det operativa ansvaret läggs på HR-avdelningen hamnar fokus lätt på frågor om könsbalans på olika positioner, ökad transparens i re- 
kryteringsprocesser och analyser av berednings- och beslutsprocesser, eftersom det är centrala frågor för denna avdelning. Intresset tenderar att inriktas på att arbeta med åtgärder som tar sikte på att utforma verktyg för att öka andelen kvinnor. Det här ser vi vid flera av de stora universiteten men också hos mindre högskolor. Arbetet riskerar därför också att bli en anpassning till rådande kultur snarare än ett arbete för förändring av densamma.

Ett exempel på en konkret åtgärd som återkommer i flera planer handlar om att jämställdhetsintegrera lärosätenas egna, interna utbildningar, framförallt sådana riktade till chefer. Aktiviteterna bygger på en problematisering av bristande kunskaper om genus och normkritik i organisationen. Detta skulle kunna öppna upp för möjligheterna att arbeta med kulturen och med sikte på ett förändringsarbete men planerna visar snarast på en otydlighet i fråga om hur långt man är benägen att gå och vad arbetet ska syfta till. Att erbjuda kompetensutveckling och utbildning blir därför tvetydigt som åtgärd. Vilka antar erbjudandet och vilka gör det inte? Hur följs dessa utbildningar upp och vad innehåller de? Det handlar sällan om att ta fram nya utbildningar utan om att integrera ett jämställdhetsperspektiv i redan existerande ledarskapsutbildningar eller högskolepedagogiska kurser. På så vis kan åtgärden resultera i förbättrade kunskaper hos de som själva väljer att ta del av utbudet, vilket inte nödvändigtvis leder till att maktordningar synliggörs och förändras.

\section{JÄMSTÄLLDHETSINTEGRERING MED FÖRÄNDRINGSPOTENTIAL}

Den speciella karaktären på planerna såsom inriktningsdokument gör att organiseringen av arbetet blir än mer centralt. Någon eller några måste bära ansvaret för den fortsatta konkretiseringen och implementeringen. Planerna innehåller också ofta en beskrivning av organiseringen, dels gällande upprättandet av planen, dels för det fortsatta arbetet. Det handlar både om det övergripande ansvaret och om den operativa samordningen. I enlighet med regeringsuppdraget ligger det yttersta ansvaret på rektor, som har godkänt och fattat beslut om planerna. Gemensamt för lärosätena är att rektor delegerat ansvaret till någon i rektors ledningsråd, ofta prorektor. Lärosätena har därefter lagt ut ett operativt ansvar på en eller flera centrala samordnare. Vid vissa lärosäten har uppdraget som samordnare inneburit att nya positioner och tjänster skapats och i några fall har personer med hög legitimitet inom kunskapsfältet utsetts som både samordnare och operativt ansvariga. Mest tydligt är detta i planen från KTH (Kungliga Tekniska högskolan) där det övergripande ansvaret lagts på en person med hög legitimitet inom organisationen (vice rektor) men även med hög legitimitet inom kunskapsområdet (professor inom genus och organisation).

I planen från KTH beskrivs också hur arbetet med jämställdhetsintegrering inneburit andra förändringar av högskolans organisering i och med inrättandet av ett Equality Office. Till detta knyts flera heltidstjänster, lokala samordnare vid högskolans olika skolor samt en vetenskaplig referensgrupp som rådgivande organ. Det här är det mest genomgripande exemplet på en förändring av organisationsstrukturen och av lednings- och styrsystemet.

Vi ser i planerna också flera andra exempel på aktiviteter med en sådan förändringspotential, det vill säga som innebär ett tydligt skifte i sättet att arbeta med jämställdhetsfrågor. I planen från Lunds universitet står exempelvis:

Universitetets mål för jämställdhetsarbetet de senaste åren har ofta tenderat att vara kvantitativa, kopplat till återrapporteringskrav som funnits i universitetets regleringsbrev. De kvantitativa målen kvarstår, men uppdraget om jämställdhetsintegrering öppnar upp för ett mer kvalitativt perspektiv, med förändrad 
kultur och maktfördelning som bidragande faktorer. (s. 2)

Uppdraget om jämställdhetsintegrering har därför också inneburit att vissa lärosäten har riktat ett kritiskt perspektiv mot pågående eller tidigare jämställdhetsarbete. I exempelvis planen från Högskolan i Halmstad $(\mathrm{HH})$ skrivs detta fram:

Vid HH har ett meriteringsprogram för kvinnor genomförts med goda resultat. Trots detta måste denna typ av insatser ses som något kortsiktigt och inte något som leder till permanenta förändringar då det gäller kvinnors möjligheter att meritera sig. (s. 14)

Problemformuleringarna i flera planer tar resonemanget om bristande kunskaper om genus $\mathrm{i}$ organisationen ett steg längre än vad vi såg ovan (i samband med internutbildningarna) och placerar uppdraget inom ramen för ett forskningsbaserat förändringsarbete. Komplexiteten i jämställdhetsintegreringen kräver helt enkelt en viss kunskapsbas, både hos samordnarna och $\mathrm{i}$ organisationen som helhet. I planen från Malmö universitet betonas detta:

De som ska leda förändringen måste förstå uppdraget ur såväl teoretiskt som praktiskt och organisatoriskt perspektiv. Förståelse för uppdraget handlar om att identifiera och acceptera problembilden och dess komplexitet samt utveckla idéer om hur de identifierade problemen kan lösas. När det gäller jämställdhetsintegrering krävs kunskap om vad genusperspektiv innebär, vad ett normkritiskt perspektiv och förhållningssätt innebär, samt hur intersektionella perspektiv kan användas (...). Att förstå hur genus görs i den egna verksamheten är en förutsättning för att kunna förändra. (s. 16)

Flera planer innehåller därför också en redovisning av forskning och tidigare projekt inom jämställdhetsområdet vid lärosätet. I planen för KTH är denna genomgång särskilt omfattande och det sägs explicit att "forskningen utgör en referensram för planen" (s. 6). Liknande kopplingar till forskningsfältet finns också exempelvis i planerna från Linköpings universitet, Karlstads universitet och Högskolan Väst. I planen från Linköpings universitet leder detta till att en tydligare agenda formuleras utifrån att strukturer och rutiner formar komplexa, osynliga/omedvetna maktordningar.

Högskolan i Gävle skiljer ut sig genom att presentera en åtgärd som innebär en obligatorisk poängsatt utbildning i genus och jämställdhet för samtliga chefer i syfte att på ett tidigt stadium "integrera alla cheferna i jämställdhetsarbetet, detta för att säkerställa vikten av att ansvaret för integreringsprocessen hamnar på rätt nivå och springer ur lokal probleminventering." (s. 2 ). Resultatet av detta skulle kunna bli en mer genomgripande kompetenshöjning i verksamheten, och skapa en förutsättning för den reella förändring som ministern för högre utbildning och forskning efterfrågade 2016 (Hellmark Knutsson 2016, se citat ovan).

\section{JÄMSTÄLLDHETSINTEGRERING UTIFRÅN FYRA TOLKNINGSRAMAR}

Utifrån teorierna om de fyra tolkningsramarna kommer vi fortsättningsvis att diskutera huruvida möjligheterna till att lärosätenas arbete med jämställdhetsintegrering kommer att innebära den genomgripande förändring som regeringsuppdraget åsyftar.

Analysen visar att jämställdhet alltjämt tolkas som något som berör enbart kvinnor. Det är en problematisering som faller inom den första tolkningsramen som definierats som 'fixing the women' (Ely och Meyerson 2000; Meyerson och Kolb 2000) och som antar att om kvinnor bara får hjälp på vägen kommer balansen mellan könen att se annorlunda ut. Ett exempel på detta är stödåtgärder för att 'hjälpa kvinnor att säga nej' till vissa arbetsuppgifter, framförallt inom grundutbildningen, som ger dem 
sämre karriärförutsättningar när det gäller forskning. Det tycks dock ha skett en tydlig förskjutning då den här typen av åtgärder, även om de förekommer, inte dominerar i planerna (jfr. Lewander och Jordansson 2000).

Flera planer identifierar en problematik som handlar om vad som skulle kunna definieras som akademiskt hushållsarbete (Bird, Litt och Wang 2004; Kalm 2019), det vill säga administrativt arbete kopplat till forskning och utbildning som kvinnor tenderar att göra i högre omfattning än män. Vid exempelvis Högskolan Väst, Linnéuniversitetet och Högskolan i Borås handlar det om att problematisera vad som värdesätts inom akademin och förändra meriteringssystemet för att öka värdet på insatserna inom grundutbildningen i relation till forskningsexcellensens företräde. Det här skulle kunna förstås inom den andra tolkningsramen som betonar att uppvärdera kvinnors 'olikhet' (Ely och Meyerson 2000). Konsekvenserna av sådana åtgärder riskerar dock att snarare stärka ett redan existerande system med en upprätthållen hierarki både mellan områdena och mellan kön. Den här typen av åtgärder kan därför ses som anpassning till rådande kultur. Möjligheterna för enskilda kvinnor att meritera sig förbättras samtidigt som strukturellt baserade ojämställda förhållanden inte utmanas. Detta sätt att arbeta skulle därför även kunna ses som att fokus ligger på att skapa lika möjligheter snarare än på att utmana normer och maktrelationer (Ely och Meyerson 2000).

När jämställdhetsintegreringen nu ska genomföras med en oklar relation till det tidigare och pågående arbetet med likavillkor utifrån diskrimineringsgrunderna tenderar det således att ske inom de tre första tolkningsramarna (Ely och Meyerson 2000). Det blir en utmaning för lärosätena att förflytta fokus - från de förbättringsåtgärder som handlar om att hjälpa kvinnor på vägen, uppvärdera sådant som kvinnor gör samt åtgärder som syftar till könsbalans
- till ett förändringsarbete med sikte på att utmana kulturen.

Planerna visar dessutom att jämställdhetsarbetet vid samma lärosäte kan röra sig över och mellan de olika tolkningsramarna på ett sätt som kan leda till motsättningar och diffusa gränsdragningar mot tidigare arbetssätt eftersom ramarna bygger på olika förståelser av uppdraget. Lika möjligheter i karriärhänseende tolkas i en del planer som att kvinnor - och ibland även andra grupper - behöver hjälp på vägen och i andra som att det handlar om en förståelse som ligger inom ramen för en strukturell obalans. Det ligger då nära till hands att åtgärderna faller inom ramen för likavillkorsarbetet. När det samtidigt presenteras som att det ska genomföras genom att utmana kulturen, anlägga ett normkritiskt perspektiv och problematisera maktordningar väcks frågan hur detta i praktiken ska gå till.

Skrivningarna som används i planerna gör att det blir otydligt för läsaren vad som ska stå i fokus, och sannolikt även för lärosätena själva. Ett exempel är en högskola som å ena sidan vill förändra karriärvägar som tar en utgångspunkt i traditionella föreställningar om den manlige forskaren och å andra sidan lyfter fram att kvinnor är viktiga som förebilder och som handledare. Det är inte nödvändigtvis fler kvinnor i sig som bidrar i förändringen. Det skulle lika gärna kunna leda till anpassningar till rådande ideal. Insatser som planeras för att förändra riskerar alltså samtidigt att leda till ett upprätthållande av de sociala praktiker som reproducerar ojämställdheten.

De planer som innehåller omfattande genomgångar av forskning och tidigare projekt visar dock hur maktordningar kan utmanas via synliggörande och medvetna strategier som bygger på den kompetens som finns inom forskningen. Det här betyder förutsättningar för ett arbete i enlighet med den fjärde tolkningsramen, som innebär att kulturen utmanas (Ely och Meyerson 2000; Meyerson och Kolb 2000). Här kan även likavillkorsarbetet innebära en 
öppning. I flera av dessa planer finns skrivningar som visar att sammankopplingen med likavillkor kan bidra till att jämställdhetsintegrering kopplas till ett arbete med fokus på normkritik och normmedvetenhet med stor förändringspotential.

Den möjliga framgången bygger emellertid på att den komplexa relationen till likavillkorsarbetet blir klarlagt. Analysen i den här artikeln problematiserar kopplingarna mellan det sedan tidigare pågående likavillkorsarbetet och det senaste uppdraget om jämställdhetsintegrering. Att förena det lagstyrda arbetet utifrån diskrimineringsgrunderna och det målstyrda arbetet med sikte på integrering av jämställdhet och långsiktig förändring riskerar att leda till ett arbete präglat av otydlighet. Det kommer att handla om att de två olika logikerna, med delvis olika utgångspunkter, ska mötas i ett konkret arbete. Fördelarna med att bygga vidare på tidigare organisations- och arbetsformer är att en lång tradition och kompetens tas till vara. Nackdelen är att arbetet riskerar att bli avpolitiserat och en fråga om administration snarare än om transformation av maktförhållanden (jfr. Alnebratt och Rönnblom 2016).

\section{SAMMANFATTANDE DISKUSSION}

Syftet med vår analys har varit att undersöka hur uppdraget om jämställdhetsintegrering återspeglas i lärosätenas planer. Resultaten har visat hur planerna återspeglar uppdraget om jämställdhetsintegrering genom olika tolkningsramar. Utgångspunkten för analysen har varit att dessa ramar begränsar respektive möjliggör ett framgångsrikt arbete med jämställdhetsintegrering. Planerna, som policy dokument, beskriver nämligen inte bara aktiviteter, de innebär också startpunkten för operationaliseringen av dessa (Saarinen 2008).

Samtliga fyra tolkningsramar som legat till grund för analysen förekommer i planerna. I hög grad är det de tre första ramarna, vilka kan karaktäriseras utifrån förbätt- ringsåtgärder, som dominerar (jfr. Ely och Meyerson 2000; Meyerson och Kolb 2000). Kvinnor kan här visserligen få ökade möjligheter men det sker till priset av en anpassning till rådande kultur snarare än den genomgripande förändring som uppdraget syftar till. En förändring skulle kräva att den fjärde tolkningsramen används, det vill säga att aktiviteter som utmanar kulturen och de normer och värderingar som upprätthåller ojämställdheten utvecklas (jfr. Ely och Meyerson 2000). Det finns exempel $\mathrm{i}$ vårt material som går $\mathrm{i}$ denna riktning men det är för tidigt att säga något om vad det kan leda till.

Det finns vidare en risk att det fortsatta arbetet kan komma att präglas av paradoxer och motsägelsefullhet. Inte minst eftersom både problematiseringar och åtgärder kan kopplas till otydlighet när det gäller vilka tolkningsramar som ligger till grund.

Analysen sätter också frågan om legitimitet $\mathrm{i}$ fokus och synliggör dessutom flera aspekter av legitimitet. Det handlar bland annat om att arbetet måste få legitimitet $\mathrm{i}$ förhållande till ledningen, vilket varit problem i tidigare projekt och som därför trots framgångar inom sina respektive områden - tenderat att ha blivit kortsiktiga och beroende av de personer som drivit arbetet (Lewander och Jordansson 2000; Lindholm 2014; SOU 2011:1). Hur arbetet är organiserat är därför en kärnfråga för möjligheterna att nå ut $\mathrm{i}$ verksamheterna. Det är dock svårt att dra några slutsatser utifrån de organisationsformer som presenteras i planerna. Det handlar nämligen inte enbart om hur arbetet organiseras utan i vilken utsträckning personer med kunskap och möjlighet att bedriva ett förändringsarbete är involverade i processerna.

Det är inte givet att något händer bara för att personer på ledande positioner i organisationen har involverats och uppmanar verksamheterna att driva arbetet vidare. Snarare riskerar spänningen mellan linjestyrningen och kollegialiteten i akademin att synliggöras (jfr. Jordansson 2005). 
Myndighetsutövandet, som här representeras av chefer på olika nivåer, kommer att möta medarbetare som, utifrån en professionell kollegialitet, inte vill se sig styras. Förändringsarbetet förutsätter därför också legitimitet i organisationen. Ett första steg i detta är att arbetet behöver vara forskningsförankrat. De planer som beskriver goda möjligheter att driva ett förändringsarbete ger också uttryck för just betydelsen av att knyta kompetens baserad på forskning om genus och maktordningar till arbetet. På så vis tydliggörs uppdraget och motiven för att arbeta med frågorna byggs under med kunskap, vilket i sig kan vara ett steg mot att uppnå ökad legitimitet för arbetet (jfr. Powell 2016).

Det allra tydligaste resultatet av analysen av planerna har varit variationen i hur uppdraget, och jämställdhetsintegrering, tolkas. Den här bilden kompletterar resultaten från Nielsens (2014) studie av jämställdhetsplaner vid lärosäten i Sverige, Norge och Danmark. Medan Nielsen synliggör skillnader mellan länderna vad gäller jämställdhetsdiskurser, och betonar likheterna inom länderna, så visar vår analys att den svenska högskolevärlden på intet sätt är homogen. Bilden som Nielsen ger, som bygger på ett begränsat urval och en jämförelse mellan endast två likartade universitet i tre olika länder, gagnas av att problematiseras. Det är stora skillnader mellan de olika lärosätena i Sverige och det finns stora skillnader mellan dem också vad gäller hur de problematiserar, förstår och argumenterar för jämställdhet.

\section{REFERENSER}

- Alnebratt, K. 2009. Meningen med genusforskning såsom den framträder i forskningspolitiska texter 1970-2000, Diss. Gothenburg gender studies; 6. Göteborg: Acta Universitatis Gothoburgensis. - Alnebratt, K. och Rönnblom, M. 2016. Feminism som byråkrati, Stockholm: Leopard förlag. - Angervall, P. 2005. Jämställdhetsarbetets pedagogik. Dilemman och paradoxer $i$ arbetet med jäm- ställdhet på ett företag och ett universitet, Diss. Göteborg: Studies in Educational Sciences, Göteborgs universitet.

- Benner, M. 2001. Kontrovers och konsenus. Vetenskap och politik $i$ svenskt 1990-tal, SISTER rapport 1. Nora: Bokförlaget Nya Doxa.

- Bird, S., Litt, J. och Wang, Y. 2004. Creating Status of Women Reports: Institutional Housekeeping as "Women's Work". NWSA Journal. 16(1), 194-206.

- Bremer, K. 2015. Utvecklad ledning av universitet och högskolor. SOU 2015:92. Stockholm: Fritzes.

- Dahlerup, D. 2010. Jämstalldhet $i$ akademin. En förskningsoversikt. Stockholm: Delegationen for jämstalldhet i hogskolan.

- Dir 2009:7. Kommittédirektiv Delegationen för jämställdhet i högskolan, Svart på vitt - om jämställdhet $i$ akademin. Betänkande av Delegationen för jämställdhet i högskolan (SOU 2011:1), bilaga 1. Stockholm: Delegationen för jämställdhet i högskolan.

- Ely, R. J. och Meyerson, D. E. 2000. Theories of gender in organizations: a new approach to organizational analysis and change. Research in Organizational Behaviour. 22, 103-151. DOI:

https://doi.org/10.1016/S0191-

3085(00)22004-2

. Finfgeld-Connett, D. 2014. Use of content analysis to conduct knowledge-building and theory-generating qualitative systematic reviews. Qualitative research. 14(3), 341-352. DOI: https://doi.org/10.1177/1468794113481790 - Heikkilä, M. och Häyrén Weinestål, A. 2009. Kartläggning och analys av jümställdhetsinsatser vid svenska lärosäten 2000-2009. Stockholm: Delegationen för jämställdhet i högskolan.

- Hellmark Knutsson, H. 2016. Nu ska alla högskolor öka jämställdheten. Dagens Arena. Tillgänglig på http://www.dagensarena.se/opinion/helene-hellmark-knutsson

· Högskoleförordningen 1993: 100. Svensk författningssamling.

· Högskolelagen 1992: 1434. Svensk författningssamling.

- Jordansson, B. 1999. Jämställdhetspolitikens villkor. Politiska intentioners möten med den akademiska världen: exemplet "Thamprofessurerna". Rapport 1/99. Göteborg: Nationella sekretariatet för genusforskning.

· Jordansson, B. 2005. Jämställdhet och genus på akademins villkor. Två exempel på det vetenskapliga fältets agerande i samband med politiska satsningar. Kvinnovetenskaplig tidskrift. 26(4), 23-41. - Jordansson, B. 2017. Gender equality in the 
Swedish educational sector: A case study on Swedish academia. In: Biswas, U. N., Allard, K., Pousette, A. och Härenstam, A. eds. Understanding Attractive Work in a Globalized World. Studies from India and Sweden. Singapore: Springer, 225240.

· Kalm, S. 2019. Om akademiskt hushållsarbete och dess fördelning. Sociologisk forskning. 56(1), 5-26.

- Lewander, L. och Jordansson, B. 2000. Genus och jämställdhet. En utvärdering av JÄST-projekten 1993/94 - 1996/97. Stockholm: Högskoleverket.

- Liinason, M. 2010. Institutionalized Knowledge: Notes on the Processes of Inclusion and Exclusion in Gender Studies in Sweden. NORA - Nordic Journal of Feminist and Gender Research. 18(1), 38-47. DOI:

https://doi.org/10.1080/08038741003626973

- Lindholm, K. 2014. Från plan till praktik. En

studie om förutsättningar och utmaningar $i$ arbetet för lika rättigheter och möjligheter. DO Rapport

2014:3. Stockholm: Diskrimineringsombudsmannen.

- Marshall, C. 1999. Researching the margins: Feminist critical policy analysis. Educational Policy. 13(1), 59-76. DOI:

https://doi.org/10.1177/0895904899131006

- Merton, R. 1973. The Sociology of Science. Cambridge: Polity Press.

- Meyerson, D. E. och Kolb, D. M. 2000. Moving out of the 'armchair': Developing a framework to bridge the gap between feminist theory and practice. Organization. 7(4), 553-571. DOI: https://doi.org/10.1177/135050840074003

- Muhonen, T., Liljeroth, C. och Scholten, C. 2012. Vad innebär jämn könsfördelning på mellanchefsniva för den kvalitativa jämställdheten i organisationen? Malmö: Malmö högskola.

- Nielsen, M. W. 2017. Scandinavian Approaches to Gender Equality in Academia: A Comparative Study. Scandinavian Journal of Educational Research. 61(3), 295-318. DOI: https://doi.org/ 10.1080/00313831.2016.1147066

- Nielsen, M. W. 2014. Justifications of Gender Equality in Academia: Comparing Gender Equality Policies of Six Scandinavian Universities. NORA Nordic Journal of Feminist and Gender Research. 22(3), 187-203. DOI: https://doi.org/10.1080/ 08038740.2014 .905490

- Peterson, H. 2017. Gender and prestige in Swedish academia: Exploring senior management in universities and university colleges. Scandinavian Journal of Educational Research. 61(1), 1-17.

- Peterson, H. och Jordansson, B. 2017. Gender equality as a core academic value: Undoing gender in a 'non-traditional' Swedish university. In:

White, K. och O'Connor, P. eds. Gendered Success in Higher Education. London: Palgrave Macmillan, 27-47.

- Powell, S. 2016. Gender Equality and Meritocracy. Contradictory discourses in the Academy. Diss. Uppsala: Swedish University of Agricultural Sciences.

. Prop. 1992/93:169. Om högre utbildning för ökad kompetens. Stockholm: Regeringskansliet. - Prop. 1992/93:170. Forskning för kunskap och framsteg. Stockholm: Regeringskansliet.

- Prop. 1993/94:147. Jämställdhetspolitiken. Delad makt-Delat ansvar. Stockholm: Regeringskansliet.

- Prop. 1994/95:164. Jämställdhet mellan kvinnor och män inom utbildningsområdet. Stockholm: Regeringskansliet.

. Prop. 1996/97:5. Forskning och sambälle. Stockholm: Regeringskansliet.

- Prop. 1996/97: 141. Högskolans lärare, ledning och organisation. Stockholm: Regeringskansliet.

- Prop. 2009/10:149. En akademi $i$ tiden - ökad fribet för universitet och högskolor. Stockholm: Regeringskansliet.

- Prop. 2016/17:50. Kunskap i samverkan - för sambällets utmaningar och stärkt konkurrenskraft. Stockholm: Regeringskansliet.

- Regleringsbrev för budgetåret 2016 avseende universitet och högskolor. Regeringsbeslut. 201512-18 III:4. U2015/01913,05184/UH, U2015/04976/UH(delvis), U2015/05895/SAM(delvis), $\mathrm{U} 2015 / 05953 / \mathrm{UH}$

· Rönnblom, M., Amundsdotter, E., Carbin, M. och Keisu, B. 2014. Hållbar strukturell förändring - möjlighet eller utopi? Slutrapport från ett projekt finansierat av Delegationen för jämställdhet i högskolan. Stockholm: Delegationen för jämställdhet i högskolan.

- Saarinen, T. 2008. Position of text and discourse analysis in higher education policy research. Studies in Higher Education. 33(6), 719-728. DOI: https://doi.org/10.1080/03075070802457090 - Sandström, U., Wold, A., Jordansson, B., Ohlsson, B. och Smedberg, Å. 2010. Hans Excellens. Om miljardsatsningarna på starka forskningsmiljöer. Rapport 2010:4. Stockholm: Delegationen för jämställdhet i högskolan.

- SCB 2004. Könsuppdelad statistisk. Ett nödvändigt medel för jümställdhetsanalys. CBM 2004:1. Örebro: Statistiska centralbyrån.

. SFS 2008:567. Diskrimineringslag. Svensk författningssamling. Stockholm: Regeringskansliet. 
- SOU 1995:110. Viljan att veta. Viljan att förstå. Kön, makt och den kvinnovetenskapliga utmaningen i högre utbildning. Stockholm: Fritzes.

. SOU 2008:104. Självständiga lärosäten. Betänkande av Autonomiutredningen. Stockholm: Fritzes.

. SOU 2011:1. Svart på vitt - om jümställdhet $i$ akademin. Betänkande av Delegationen för jämställdhet $i$ högskolan. Stockholm: Fritzes.

- Statskontoret 2014. Forskningsanslagen ur ett genusperspektiv. Rapport: 2014:27.

(U2013/6713/JAM). Stockholm: Statskontoret. . UHR 2014. Jämställdhet i högskolan - ska den nu ordnas en gaing för alla? Redovisning av regerings- uppdrag till Universitets- och högskolerådet. Stockholm: UHR.

. UKÄ 2018. Årsrapport för universitet och högskolor. Rapport 2018:5. Stockholm: Universitetskanslersämbetet.

. Winther Forsbäck, J. 2017. Med dubbla syften. Forum för kvinnliga forskare, aktivism och statsfeminism 1975-1995. Diss. Göteborg: Avhandling från Institutionen för Historiska Studier, Göteborgs universitet.

. Öhrn, E. och Lundahl, L. red. 2013. Kön och karriär $i$ akademin. En studie inom det utbildningsvetenskapliga fältet, Göteborg: Acta Universitatis Gothoburgunsis, Göteborgs universitet. 